\title{
Marka Mağaza Zincirlerindeki Pazarlama ve Satış Görevli Cinsiyetlerinin Müşterilerin Satın Alma Algılamalarındaki Önemi ve İncelenmesi: Forum Mersin Örneği
}

\author{
Ruhan İRI \\ Niğde Ömer Halisdemir Üniversitesi \\ ruhaniri@ohu.edu.tr \\ ORCID ID: 0000-0002-5981-9673
}

Araştırma Makalesi
Geliș Tarihi: 03.10.2020

Revize Tarihi: 26.03.2021

DOI: $10.31592 /$ aeusbed.804881

Kabul Tarihi: 29.03.2021

\section{Atıf Bilgisi}

İri, R. (2021). Marka mağaza zincirlerindeki pazarlama ve satış görevli cinsiyetlerinin müşterilerin satın alma algılamalarındaki önemi ve incelenmesi: Forum Mersin örneği. Ahi Evran Üniversitesi Sosyal Bilimler Enstitüsü Dergisi, 7(1), 375-388.

\section{$\ddot{O Z Z}$}

Araştırma, kurumsal marka işletme mağazalarındaki pazarlama ve satış görevlilerinin cinsiyetlerinin müşterilerinin satın alma eğilimine yönelik algılarındaki önemini ve etkisini ortaya koymak ve literatüre katkı sağlamak amacıyla hazırlanmıştır. Araştırma 01-31 Ağustos 2020 tarihleri arasında, çalışmanın örneklemini oluşturan Mersin şehri Forum Mersin Alışveriş Merkezi içerisinde, yargısal olarak seçilen ve kurumsal işletme veya marka işletme mağaza zincirlerinden alışveriş yapan 555 tüketiciyle yüzyüze yapılan anketlerden elde edilen verilerin analiz edilmesiyle gerçekleştirilmiştir. Araştırma için, Niğde Ömer Halisdemir Üniversitesi Etik Kurulu 28.07.2020 tarih ve 86837521-050.99-E.32490 Etik Kurul say1 numarasıyla gerekli izin gerekli izin verilmiştir. Yapılan analizlere dayanarak, kurumsal işletme (marka) mağazalarındaki pazarlama ve satış görevli cinsiyetlerinin müşterilerin satın alma eğilimine yönelik tutum ölçeğinin, sadece işletmelerin pazarlama ve satış görevlilerinin cinsiyet tercihlerinin işletmeler arasındaki rekabette önemli olması ile ölçek faktörleri arasında anlamlı bir farklılık çıkmıştır. Farkın kaynağını tespit etmek amacıyla yapılan Tukey testinde; işletmelerin pazarlama ve satış görevlilerinin cinsiyet tercihlerinin işletmeler arasındaki rekabette önemli olmasında anlamlı bir farklılık arasında, kadın pazarlama ve satış görevlileri lehine olduğu sonucuna ulaşılmıştır.

Anahtar Kelimeler: Marka, işletme, pazarlama, cinsiyet, Mersin.

\section{The Importance and Analysis of the Gender of the Marketing and Sales Officers in the Brand Store Chains towards Purchase Perception of the Customers: Forum Mersin Example}

\begin{abstract}
The study has been prepared in order to reveal the importance and effect of the gender of marketing and salespeople in corporate business (brand) stores towards the perceptions of customers' purchasing tendencies and to contribute to the literature. The research was conducted by analyzing the data obtained from face-toface surveys conducted with 555 consumers who were judgmentally selected from the city of Mersin, Forum Mersin Shopping Center, corporate workplace or brand business store chains between 01-31 August 2020. The required permission was received from Niğde Ömer Halisdemir University Ethics Committee for the Ethics Committee research dated 28.07.2020 and numbered 32490. According to the analysis, a significant difference was found between the scale factors of the marketing and salesperson gender attitude scale and the scale factors for the purchasing tendencies of customers in corporate business (brand) stores and the gender preferences of marketing and sales representatives. In Tukey test conducted to determine the source of the difference, it was concluded that there is a significant difference in the fact that gender preferences of marketing and sales personnel of companies are important in favor of female marketing and sales personnel in the competition between enterprises.

Keywords: Brand, business, marketing, gender, Mersin.
\end{abstract}

\section{Giriş}

Tüketici davranışlarının pazarlama yöneticilerinin her zaman takip ettiği bir alan olmasının sebepleri arasında, tüketici davranışlarının sürekli ve hızlı değişimi, dinamik olması ve güncellenmeye ihtiyaç duyulması yer almaktadır (Tayfun, 2015, s. 88). Tüketicilerin satın alma davranışlarını etkileyen bireysel faktörler arasında yer alan cinsiyet değişkenine göre müşterilerin satın alma davranışlarında ortaya çıkan farklılıklar, işletme pazarlama ve satış görevli cinsiyetlerinin de, tüketici satın alma kararında veya ürün ya da marka seçiminde önemli bir role sahip olabilmektedir (Peterson, 2005, s. 349). Aynı zamanda pazarlama açısından cinsiyet, satın alma sırasında tüketicilerle pazarlama veya satış görevlisi cinsiyetinin aynı veya farklı olması durumu, müşteri ile pazarlamacı ya da satıcı 
arasındaki anlaşma veya iletişimin (empati, sempati ve antipati oluşumunda) gerçekleşmesinde önemli olabilmektedir. Başta hizmet sektörü olmak üzere birçok işletmelerde müşteriler hem cins veya karş1 cins çalışanlardan pazarlama ve satış hizmeti almaktadır. Mağaza içerisinde alışveriş yapma isteği olan tüketicilerin kararlarını etkileyebilen ya da yönlendirebilen pazarlama veya satış görevlisi cinsiyetlerinin önemli olması ihtimali bu konuda araştırma yapılması gerekliliğini ortaya koymaktadır.

\section{İşletme Pazarlama ve Satış Görevli Cinsiyetlerinin Müşterilerin Satın Alma Eğilimindeki Etkisi ve Önemi}

Cinsiyet, bireye, üreme aşamasında farklı bir rol veren ve erkekle dişiyi ayırt ettiren doğuştan gelen bir (yaratılış) özelliği olmasının yanı sıra, kadın ve erkeğin sosyo-kültürel yönleriyle ve onlara verdiği toplumsal rolleri ve bunlara yönelik genel olarak kabul edilmiş işlevleri ifade etmektedir. (Strouse, 2019, s. 49-50). Cinsiyet bireyin biyolojik, fiziksel ve genetik özelliklerini tanımlayarak, erkek ve kadın olarak cinsiyeti iki genel tür kabul etmektedir (Başfirıncı, Ergül ve Özgüden, 2018, s. 200). Cinsiyet, bir canlının erkek ve dişiliğini ifade eden bir sözcüktür, biyolojik bir yapıya karşlık gelmektedir ve erillik ve dişilik arasında farklılık gösteren özellikler aralığı olup, bağlama göre, bu özellikler biyolojik cinsi (yani erkek, dişi veya erdişi olma durumunu), cinse dayalı sosyal yapıları (cinsiyet rolleri ve diğer sosyal roller de) veya cinsiyet kimliğini kapsayabilmektedir (Dökmen, 2015, s. 20).

Cinsiyet, pazarlama alanında bir pazar bölümlendirme değişkeni olmakla birlikte, tüketici davranışlarının farklılık göstermesinde bir etkendir ve pazarlama literatüründeki araștırmaların çoğunda tüketicilerin özellik, tutum ve davranışlarında cinsiyetin etkisi incelenmektedir (Çabuk ve Araç, 2013, s. 27). Tüketim eğilimleri cinsiyetleştirilmiş ve müşteriler cinsel kimliklerini göstermek amaciyla cinsiyetine uygun ürünler ve markalara yönelmiştir (Avery, 2012, s. 3). Tüketicilerin toplumsal statüsü kullandıkları ürünler ile ilgili olduğu kadar, cinsiyete göre tüketim eğilimleri de farklılık göstermekte, doğumla elde edilen cinsiyet kimliği tüketim aracılığıyla biçimlenmekte, bireyin toplumdaki yeri, statüsü ve buna bağlı olarak elde ettiği iktidar ve gücü, toplumsal cinsiyeti ve tüketim eğilimleriyle yakından ilgili olabilmektedir (Karahan ve Adak, 2019, s. 122).

Cinsiyetin tüketici davranışında, belirli bir toplum, zaman ve kültürel birikim (kaynaklar, değerler, inançlar, normlar, geleneksel davranış kalıpları) içerisinde, cinsiyet rolleri ile ilişkilendirilen ve cinsiyetler için uygun görülen davranışlara etkisi bulunmaktadır (Arnould, Price ve Zinkhan, 2002, s. 511). Tüketicilerin bir ürünü satın almasında, en son karar vericinin erkek veya kadın olmasının alışverişi etkilemesinde önemliyse, işletme pazarlama ve satış görevli cinsiyetinin de en son karar vericilerin tercihlerini etkilemesinde önemli olduğu söylenebilir (Odabaşı ve Barış, 2007, s. 259). Tüketicilerin cinsiyetlerinin tüketim eğilimleri ve satın alma davranışları üzerinde etkili olması kadar, işletme (marka) mağazalarında çalışan pazarlama ve satış görevli cinsiyetlerinin de, müşterilerin karar verme ve satın alma eğilimine yönelik algılamaları üzerinde etkili olması mümkündür.

\section{Müşterilerin Marka İşletme Mağaza Zincirlerindeki Pazarlama ve Satış Görevlileriyle Cinsiyet Anlaşması veya İletişimi}

Cinsiyet kavramının, marka genişleme stratejilerinde işletmelere önemli avantajlar sunan bir pazarlama stratejisidir (Efe, 2017, s. 606). Bununla birlikte marka genişlemesine yönelik tüketici tutumları üzerinde, reklam sloganlarında, ambalaj tercihlerinde ve renk seçiminde önemli bir rolü bulunmaktadır ve markanın özellikle kadınsı veya erkeksi algılanmasında etkileri olmaktadır (Peker, Özkan ve Okumuş, 2017, s. 23). Markanın sahip olduğu veya pazarlama ve satış hizmeti sunduğu cinsiyetle alıcının cinsiyetinin örtüşmesi halinde markaya pazar üstünlüğü sağlayacak ve güçlü bir konumlandırma elde edecektir (Yıldırım ve Kömürcü, 2019, s. 150).

Tüketicilerin kendi cinsiyetiyle marka pazarlama ve satış görevlilerinin algılanan cinsiyeti arasındaki uyumsuzluk ileride işletmenin uygulayacağı marka genişlemesi stratejisine de olumsuz yansıyabilir (Chang ve Tung, 2016, s. 356). İşletmelerde çalışan pazarlama ve satış görevli cinsiyetlerinin müşteriler üzerinde oluşturduğu etki, marka mağaza zincirlerinde daha belirgin hale gelmekte ve ürün yapısı ve özelliğine göre pazarlama ve satış görevli cinsiyeti uyumlu olmaktadır. 
Müşterilere ürün hakkında bilgi vermek, satış yapmak ve mağazanın sorunsuz bir şekilde günlük işleyişini sağlamaktan sorumlu olan mağaza pazarlama ve satış görevlileri, müşterilerin satın alacakları ürünleri bulmaları ve seçmelerine yardımcı olmanın yanı sıra, ödeme işlemlerini gerçekleştirmektedir.

Kurumsal veya marka imaj oluşumunda işgörenlerin yaşı, eğitim durumu ile ortamın fiziki durumunun yanı sıra çalışanların cinsiyeti de etkilidir (Bal, 2012, s 226). Cinsiyet kavramı, pazarlamanın en önemli ve belirleyici değişkenlerinden biri olarak kabul edilmekte olup, pazarlamacılar ve marka yöneticileri, işletme pazarlama ve satış faaliyetlerinde sıkça kullandıkları ürün çeşit, özellik ve yapısına uyumlu olan pazarlama ve satış görevlisi cinsiyeti kavramı üzerindeki etkilerini değerlendirmektedir (Yıldırım ve Büyükateş, 2020, s. 2219). Giyim, mobilya, gıda, kozmetik, aksesuar ve teknoloji gibi birçok farklı sektörde faaliyet gösteren işletme mağazalarının faaliyetlerinde görev alan pazarlama ve satış görevlilerin cinsiyetleri ürün çeşit, özellik ve yapısına göre değişmektedir. Özellikle marka mağaza zincirlerinin sektörel yapısına göre veya ürün çeşitleri ve özelliklerine göre pazarlama ve satış görevli cinsiyetlerinin farklılık göstermesi, müşteriler ile marka işletme mağaza zincirlerinde pazarlama ve satış görevlileri arasında cinsiyet anlaşması veya iletişimini (empati, sempati ve antipati oluşumunu) olumlu veya olumsuz etkileyebilmektedir.

\section{Literatür Taraması}

İşletme pazarlama ve satış görevlilerinin müşterilerin satın alma eğilimindeki konusunda daha önceden yapılan çok sayıda çalışma olmakla birlikte, işletme pazarlama ve satış görevlilerinin cinsiyetlerinin müşterilerin satın alma eğilimine yönelik herhangi bir çalışmaya rastlanmamaktadır ve bu durum literatürde, işletme pazarlama ve satış görevlilerinin cinsiyetlerinin müşterilerin satın alma eğilimindeki önemini ve araştırılmasını dikkat çekici hale getirmiştir. Literatürde çok sayıda yer alan pazarlama ve satış görevlilerinin müşterilerin satın alma eğilimine etkisi konusunda ile ilgili araştırmalar incelendiğinde, demografik faktörlerden olan tüketicilerin cinsiyetinin satın alma eğilimleri veya satın alma aşamasındaki karar verme üzerindeki etkisi ön plana çıkmaktadır.

Tüketici davranışını etkileyen faktörleri konu alan literatürdeki çalışmalarda yaygın olarak kullanılan kriterlerden biri cinsiyettir (Kılıçer, Boyraz ve Tüzemen, 2016, s. 131). Cinsiyet farklılığı tüketicilerin kendisine özgü yeteneklere, tutumlara, önceliklere ve tercihlere sebep olmakta ve bu farklılıklar pazarlama açısından önemli anlamlara sahiptir (Barletta, 2003. ss. 16-17). Fischer ve Arnold (1990) Christmas alışverişlerinde tüketicilerin cinsiyet rolünün etkisi olduğunu belirtmişlerdir (Fischer ve Arnold, 1990, s. 342).

Cleveland, Babin, Laroche, Ward ve Bergeron (2003), tatilde hediyelik eşya alı̧̧eriş yapan kadınların ürüne özgü ve çevresel bilgi kaynaklarını erkeklerden daha fazla kullandığını, erkeklerin ise pazarlama ve satış görevlisi yardımından daha fazla yararlandığını ortaya koymaktadır (Cleveland vd., 2003, s. 20). Bakshi (2012), tüketici satın alma kararının her aşamasında cinsiyet davranışlarının tamamen zit olduğunu ve rekabet avantajı elde etmek için pazarlamacıların bu farkı en iyi şekilde yakalamaları gerektiğini belirtmişlerdir (Bakshi, 2012, s. 7). Karahan (2018), tüketim toplumunda alışverişin cinsiyeti çalışmasında, hem kadınların, hem de erkeklerin yoğun bir tüketim eğiliminde olduklarını, ancak satın alınan ürünlerin toplumsal cinsiyete bağlı olarak farklılaştığını ortaya koymuştur (Karahan, 2018, s. 195).

Karahan ve Adak (2019), cinsiyet fark etmeksizin hem kadınların hem de erkeklerin ihtiyaçları doğrultusunda alışverişe gittikleri gibi haz odaklı da alışveriş yaptıklarını ortaya koymuşlardır (Karahan ve Adak, 2019, s. 142). Arnold ve Bianchi (2001), ilişkisel pazarlama stratejilerini müşterilere ilişkisel olma olasıllkları temelinde yönlendirmeyi önermekte ve ilişkisel olmalarında biyolojik cinsiyetlerine ve/ veya cinsiyetlerine ve ayrıca kültürel yönelimlerine bağlı olacağını belirtmişlerdir. Akdoğan ve Karaarslan (2010), işletme mağazaları içerisinde tüketicinin kararını yönlendiren kişilerin etkisinin senaryo yöntemi ile ölçülmesi isimli çalışmada, satış 
görevlilerinin tüketicileri yönlendirebildikleri ve k1z öğrencilerin erkek öğrencilere göre satış görevlilerinin yönlendirmelerine daha olumlu tepki verdiklerini ortaya koymuştur.

Lieven (2016), perakendecilikte, bir müşterinin satış görevlisi ile ilk karşılaşmasının çok önemli olduğunu ve kolayca fiziksel, görev veya sosyal çekicilik gibi erişilebilir ipuçları seçimde yardımcı olabileceğini ve satış görevlisi cinsiyetinin de müşteri ile iletişimde önemli olduğunu belirtmiştir (Lieven, 2016, ss. 114-115). Grohmann (2009), markaları erkeksi veya kadınsı olma durumlarına göre düzenleme becerisinde yarışan markaların, müşteri algısını ve konumlandırma stratejilerini tanımada bir araç olarak kullanılabileceğini belirledi (Grohmann, 2009, s. 116). Yağcı ve İlarsan (2010), Tüketicilerin gelir düzeyi yükseldikçe, cinsiyetler arasındaki ayrımlar azaldığını ortaya koymuştur (Yağc1 ve İlarsan, 2010, s. 150).

Tanrıkulu (2017), satış gücündeki iş sonuçlarına ilişkin cinsiyet farklılıkları ve cinsiyet kimliği farkl1liklarının zaten var olduğunu ve androjen bireylerin satış mesleği için en uygun cinsiyet kimliğine sahip olduğunu belirlemiştir (Tanrıkulu, 2017, s. 499). Acar (2012), cinsiyetle kurumsal marka değerinin algılanmasını incelediği araştırmasında, iki cins arasında bir ayrımın söz konusu olmadığını ancak tüketicilerin kurumsal markayı önemsedikleri sektörle cinsiyet arasında ilişki bulunduğunu belirlemiştir (Acar, 2012, s. 118).

\section{Marka Mağaza Zincirlerindeki Pazarlama ve Satış Görevli Cinsiyetlerinin Müşterilerin Satın Alma Algılamalarındaki Önemi ve İncelenmesine Yönelik Forum Mersin Alışveriş Merkezinde Yapılan Bir Araştırma}

Marka mağaza zincirleri ve tüketicilerin satın alma eğilimleri arasındaki ilişki ile ilgili kavramlar üzerine literatürde pek çok araştırma yapılmasına rağmen, marka mağaza zincirlerindeki pazarlama ve satış görevli cinsiyetlerinin müşterilerin satın alma algılamalarına yönelik akademik bir araştırma yapılmamıştır. Araştırmada marka mağaza zincirlerindeki pazarlama ve satış görevli cinsiyetlerinin müşterilerin satın alma algılamalarındaki önemi ve incelenmesi tüketicilerin alışverişlerinde pazarlamacı veya satıcı cinsiyetine dikkat etmeleri veya etkilenmelerinin belirlenmesi bakımından önemlidir. Yine marka mağaza zincirlerindeki pazarlama ve satış görevli cinsiyetlerinin müşterilerin satın alma algılamalarındaki önemi konusu, başta işletme yöneticileri olmak üzere pazarlama ve satış yöneticileri ile kamuoyu tarafından bilinmek istenmesine ihtiyaç duyulması, bu alanda araştırma yapılmasının dikkat çekiciliğini ortaya çıkarmaktadır.

\section{Araştırmanın Yöntemi}

Araştırmada gerçekleştirilen tanımlayıcı istatistikler ve tek yönlü anova analizleri, konu ile ilgili daha önce yapılmış olan araştırma sonuçları incelenmiş, elde edilen bilgiler doğrultusunda İri (2020) tarafından geliştirilen "İşletme Mağazalarındaki Pazarlama ve Satış Görevli Cinsiyetlerinin Müşterilerinin Satın Alma Eğilimine Yönelik Tutum Ölçeği” kullanılarak hazırlanan bir anket formu düzenlenmiştir. Düzenlenen anketler formları Mersin il merkezinde Forum Mersin AVM içerisinde bulunan ulusal ve uluslararası toplam 206 kurumsal (marka) işletme mağazalarından alışveriş yapan ve yargisal olarak seçilen 555 tüketicilerle yapılan yüz yüze anketlerden elde edilen veriler ile gerçekleştirilmiştir. Anketlerden elde edilen veriler SPSS 22.0 paket programında değerlendirilmiş olup, araştırmanın ana kütlesini oluşturan Mersin ve yöresinde marka mağaza zinciri işletmelerinden alışveriş yapan tüketiciler arasından yargısal olarak seçilen toplam 555 tüketici örneklem alınmıştır. Bu büyüklükteki bir örnek kitlenin, - $\% 95$ güven aralığında mevcut ana kütleyi yeterli derecede temsil edeceği varsayılmıştır.

Her bir marka işletme mağazasında (haftanın belirli bir günü veya günün belirli bir saati gözetilmeksizin) araştırma grupları oluşturulurken, yargısal/ kasıtlı (Judgemental Sampling) örnekleme yöntemiyle seçilen tüketicilere anket formları yüz yüze uygulanmıştır. Müşterilerin marka mağaza zincirlerindeki pazarlama ve satış görevli cinsiyetlerinin müşterilerin satın alma eğilimindeki etkisi ve önemiyle ilgili verilerin analiz edilmesinde bazı tanımlayıcı istatistik yöntemleri ile tek yönlü varyans 
analiz testinden faydalanılmıştır. Araştırma için Niğde Ömer Halisdemir Üniversitesi Etik Kurulu 28.07.2020 tarih ve 86837521-050.99-E.32490 Etik Kurul sayı numarasıyla gerekli izin alınmıştır.

\section{Araştırmanın Amacı ve Önemi}

Son dönemlerde tüketicilerin alışveriş yaptıkları mağazalardaki pazarlama veya satış görevlisi arasındaki cinsiyet iletişimi veya cinsiyet anlaşması konusunun işletme ürün satışları üzerinde etkili olup olmadı̆̆ pazarlamacılar tarafından tartışılmaktadır. $\mathrm{Bu}$ kapsamda araştırma, marka mağazalarındaki pazarlama ve satış görevli cinsiyetlerinin müşterilerin satın alma eğilimine yönelik algılarındaki etkisini ve önemini belirlemek amacıyla hazırlanmıştır. Alışveriş merkezlerinde marka mağaza zinciri işletmelerinden alışveriş yapan müşterilerin pazarlama ve satış görevlisi ile şikayetlerinin artması sebebiyle araştırma problemi olarak bu konu seçilmiştir. Araştırma, marka mağaza işletmelerinin bulundukları sektör ve ürün yapısına göre pazarlama ve satış görevli cinsiyet tercihlerinin müşterilerin satın alma eğilimine ve satıcı müşteri arasındaki cinsiyet anlaşmasına/iletişimine etkisinin/ öneminin tespit edilmesi bakımından önemlidir. Aynı zamanda araştırma sonuçları, Türkiye genelindeki diğer işletmelerde pazarlama ve satış görevli cinsiyeti ile müşteri cinsiyeti arasındaki iletişim sorunlarında uygulanması ve gelecek dönemlerde yapılacak araştırmalarda kullanılması bakımından da önemlidir.

Araştırma amacı doğrultusunda aşağıdaki hipotezler sorgulanmıştır:

H1: Marka mağazalarındaki pazarlama ve satış görevlisi cinsiyetlerinin müşterilerin satın alma eğiliminleri müşterilerin medeni durumuna göre fark göstermektedir.

H2: Marka mağazalarındaki pazarlama ve satış görevlisi cinsiyetlerinin müşterilerin satın alma eğiliminleri müşterilerin eğitim durumuna göre fark göstermektedir.

H3: Marka mağazalarındaki pazarlama ve satış görevlisi cinsiyetlerinin müşterilerin satın alma eğiliminleri müşterilerin yaşlarına göre fark göstermektedir.

H4: Marka mağazalarındaki pazarlama ve satış görevlisi cinsiyetlerinin müşterilerin satın alma eğiliminleri müşterilerin mesleklerine göre fark göstermektedir.

H5: Marka mağazalarındaki pazarlama ve satış görevlisi cinsiyetlerinin müşterilerin satın alma eğiliminleri müşterilerin gelir durumuna göre fark göstermektedir.

H6: Marka mağazalarındaki pazarlama ve satış görevlisi cinsiyetlerinin müşterilerin satın alma eğiliminleri müşterilerin eğitim durumuna göre fark göstermektedir.

H7: Araştırmaya katılanların satın alma eğiliminleri marka mağazalarındaki pazarlama ve satış görevlisinin cinsiyetlerine dikkat etme durumuna göre fark göstermektedir.

H8: Araştırmaya katılanların satın alma eğiliminleri marka mağazalarındaki pazarlama ve satış görevlisinin cinsiyetlerinin alış verişlerine etki etme durumuna göre fark göstermektedir.

H9: Araştırmaya katılanların satın alma eğiliminleri marka mağazalarındaki pazarlama ve satış görevlileri ile aralarındaki cinsiyet iletişimine göre fark göstermektedir.

H10: Araştırmaya katılanların satın alma eğiliminleri marka mağazalarındaki pazarlama ve satış görevli cinsiyetlerinin işletme tarafindan seçimi işletme rekabet durumuna göre fark göstermektedir.

\section{Araştırmanın Kapsamı}

Araştırma 01-31 Ağustos 2020 tarihleri arasında yapılmıştır ve Forum Mersin (AVM) Alışveriş Merkezindeki marka işletme mağazalarından alışveriş yapan tüketicileri kapsamaktadır. Alışveriş̧ merkezindeki tüketicilerin yargısal olarak seçilmesinde, marka işletme mağazaları geneli ile ilgili daha bilgili olmalarının yanı sıra araştırma kapsamında daha doğru bilgiler elde edilmesi amaçlanmıştır.

Tablo 1

Araştırma Kapsamında Yer Alan Katılımcıların Demografik Özellikleri

\begin{tabular}{lcclcc}
\hline Cinsiyet & f & \% & Yaş & f & \% \\
\cline { 1 - 3 } Erkek & 280 & 50,5 & 25 Yaş ve Altı & 129 & 23,2 \\
Kadın & 275 & 49,5 & 26-36 Yaş Arası & 169 & 30,5 \\
\cline { 1 - 2 } Medeni Durum & $\mathbf{f}$ & $\mathbf{\%}$ & 37-48 Yaş Arası & 162 & 29,2 \\
\cline { 1 - 2 } Bekar & 217 & 39,1 & 48-59 Yaş Arası & 71 & 12,8
\end{tabular}




\begin{tabular}{lcclcc} 
Evli & 318 & 57,3 & 60 Yaş ve Üzeri & 24 & 4,3 \\
Diğer & 20 & 3,6 & & & \\
\hline Eğitim & $\mathbf{f}$ & $\mathbf{\%}$ & Meslek & $\mathbf{f}$ & $\mathbf{\%}$ \\
\hline İlköğretim & 91 & 16,4 & İşçi & 83 & 14,9 \\
Lise & 236 & 42,5 & Memur & 105 & 18,9 \\
Üniversite & 183 & 33,0 & Emekli & 47 & 8,5 \\
Lişans Üstü & 39 & 7,0 & Öğrenci & 57 & 10,3 \\
Diğer & 6 & 1,1 & İşsiz & 21 & 3,8 \\
Gelir & $\mathbf{f}$ & $\mathbf{\%}$ & Çiftçi & 46 & 8,3 \\
\cline { 1 - 3 } 2000 TL'den Az & 161 & 29,0 & Akademisyen & 39 & 7,0 \\
2.001-3.000 Aras1 & 149 & 26,8 & Serbest Meslek & 75 & 13,5 \\
3.001-5.000 Aras1 & 126 & 22,7 & Ev Hanımı & 55 & 9,9 \\
5.001 TL ve üzeri & 119 & 21,5 & Diğer & 27 & 4,9 \\
\hline Toplam & & & & $\mathbf{5 5 5}$ & $\mathbf{1 0 0}$ \\
\hline
\end{tabular}

Araştırma kapsamında Mersin şehri Forum Mersin Alışveriş Merkezi içerisinde yer alan marka mağaza zincir işletmelerinden alışveriş yapan tüketicilerle anket gerçekleştirilen katılımcıların demografik özellikleri Tablo 1'de yer almaktadır.

\section{Bulgular}

Marka mağaza zincirlerinde çalışan pazarlama ve satış görevli cinsiyetlerinin müşterilerin satın alma algılamalarındaki önemi konusu, başta işletme yöneticileri olmak üzere pazarlama ve satış yöneticileri ile birlikte araştırmacıların ve kamuoyunun dikkatini çekmektedir. Araştırmada marka mağaza zincirlerinde çalışan pazarlama ve satış görevlilerinin cinsiyetlerinin müşterilerinin satın alma eğilimine yönelik düşünce düzeyleri ve algılama durumları incelenmektedir. Katılımcıların, marka mağaza zincirlerinden alışveriş yapma durumları ile marka mağaza zincirlerinden alışveriş yaparken pazarlama ve satış görevli cinsiyetlerinin alışverişlerine etkisine yönelik düşünce düzeyleri durumları tablo 2, 3, 4, 5, 6 ve 7'de yer almaktadır. Katılımcıların, marka mağazalardan alışveriş yapma durumları ile marka mağaza zincirlerinden alışveriş yaparken pazarlama ve satış görevli cinsiyetlerinin alı̧̧verişlerindeki etkisine yönelik algılama durumları ise tablo 8'de yer almaktadır.

Tablo 2

Katılımcıların Marka Mağazalarından Yılda Alıșveriș Yapma Sıklıkları Durumları

\begin{tabular}{lcc}
\hline Katılımcların Marka Mağazalarından Yılda Alışverişs & f & \% \\
Yapma Sıklıkları Durumları & 8 & 5,0 \\
En Az Bir Defa & 144 & 26,0 \\
2-5 Defa & 186 & 33,5 \\
6-10 Defa & 197 & 35,5 \\
11 Defa ve Üzeri & 555 & 100 \\
\hline Toplam & & \\
\hline
\end{tabular}

Katılımcıların önemli bir bölümü (\%95’i) y1lda en az 2 defa ve üzeri marka işletme mağazalarından alışveriş yaptıklarını belirtmektedir.

Tablo 3

Katılımcıların Marka Mă̆azalarında Alışveriş Yaparken Pazarlama ve Satış Görevli Cinsiyetlerine Dikkat Etme Durumlarl

\begin{tabular}{lcc}
\hline $\begin{array}{l}\text { Katılımcıların Marka Mağazalarında Alışveriş Yaparken } \\
\text { Pazarlama ve Satı̧̧ Görevlisi Cinsiyetlerine Dikkat Etme Durumları }\end{array}$ & f & $\mathbf{\%}$ \\
\hline Evet & 74 & 13,3 \\
Hayır & 320 & 57,7 \\
Kısmen & 161 & 29,0 \\
\hline Toplam & 555 & 100 \\
\hline
\end{tabular}


Tablo 3 'te 74 katılımcı $(\% 13,3)$ marka mağazalarında alıșveriş yaparken pazarlama ve satı̧ görevli cinsiyetlerine dikkat ettiklerini, 320'si (\%57,7) marka mağazalarından alışveriş yaparken pazarlama ve satış görevli cinsiyetlerine dikkat etmediklerini, 161'i (\%29) ise, marka mağazalarında alışveriş yaparken pazarlama ve satış görevli cinsiyetlerine kısmen dikkat ettiklerini ifade etmişlerdir.

Tablo 4

Katılımcıların Marka Mağazalarında Alışveriş Yaparken Pazarlama ve Satış Görevli Cinsiyetlerinin Alışverişlerinde Etkili Olma Durumları

\begin{tabular}{lcc}
\hline $\begin{array}{l}\text { Katılımciların Marka Mağazalarında Alısvveriş Yaparken Pazarlama ve } \\
\text { Satış Görevlisi Cinsiyetlerinin Alsşverişlerinde Etkili Olma Durumları }\end{array}$ & f & \% \\
\hline Evet & 130 & 23,4 \\
Hayır & 308 & 55,5 \\
Kısmen & 117 & 21,1 \\
\hline Toplam & 555 & 100 \\
\hline
\end{tabular}

Tablo 4'te katılımcıların marka mağazalarında alışveriş yaparken pazarlama ve satış görevli cinsiyetlerinin alışverişlerinde etkili olma durumlarına yer verilmektedir. 130 katılımcı $(\% 23,4)$ marka mağazalarında alışveriş yaparken pazarlama ve satış görevli cinsiyetlerinin alışverişlerinde etkili olduğunu, 308'i $(\% 55,5)$ marka mağazalarında alışveriş yaparken pazarlama ve satış görevli cinsiyetlerinin alışverişlerinde etkili olmadığını ve 117 'si $(\% 21,1)$ ise marka mağazalarında alışveriş yaparken pazarlama ve satış görevli cinsiyetlerinin alışverişlerinde kısmen etkili olduğunu belirtmişlerdir.

Tablo 5

Katılımcıların Marka Mă̆azalarında Alışveriş Yaparken Pazarlama ve Satı̧̧ Görevlisi Cinsiyetlerinin Müssteri İlişkilerinde ve Illetişimde Etkili Olma Durumlar

\begin{tabular}{|c|c|c|}
\hline $\begin{array}{l}\text { Katlımcıların Marka Mağazalarında Alısveriş Yaparken Pazarlama ve Satış } \\
\text { Görevlisi Cinsiyetlerinin Müş̧eri İlişkilerinde ve İletişimde Etkili Olma Durumları }\end{array}$ & f & $\%$ \\
\hline Evet & 162 & 29,2 \\
\hline Hayır & 271 & 48,8 \\
\hline Kismen & 122 & 22,0 \\
\hline Toplam & 555 & 100 \\
\hline
\end{tabular}

Tablo 5'te katılımcıların marka mağazalarında alışveriş yaparken pazarlama ve satış görevli cinsiyetlerinin müşteri ilişkilerinde ve iletişiminde etkili olma durumlarına yer verilmektedir. 162 katılımcı $(\% 29,2)$ marka mağazalarında alışveriş yaparken pazarlama ve satış görevli cinsiyetlerinin müşteri ilişkilerinde ve iletişiminde etkili olduğunu, 271'i $(\% 48,8)$ marka mağazalarında alışveriş yaparken pazarlama ve satış görevli cinsiyetlerinin müş̧eri ilişkilerinde ve iletişiminde etkili olmadığını belitmişlerdir. 122 katılımcı (\%22) ise, marka mağazalarında alışveriş yaparken pazarlama ve satış görevli cinsiyetlerinin müşteri ilişkilerinde ve iletişiminde kısmen etkili olduğunu ifade etmişlerdir.

Tablo 6

Katılımcıların Marka Mağazalarında Alışveriş̧ Yaparken Pazarlama ve Satış Görevlileri Arasında Hangi Cinsiyetle Daha İyi İletişim Kurdukları (Anlaştıkları/Sempati Duydukları) Durumları

\begin{tabular}{lcc}
\hline $\begin{array}{l}\text { Katılımcıların Marka Mağazalarında Alşveriş Yaparken Pazarlama } \\
\text { ve Satıș Görevlilerinin Hangi Cinsiyetle Daha İyi Anlaşma Durumları }\end{array}$ & f & \% \\
\hline Erkek Pazarlama veya Satış Görevlisi İle Anlaşırım & 41 & 7,4 \\
Bayan Pazarlama veya Satış Görevlisi İle Anlaşırım & 113 & 20,4 \\
Her İkisiyle de Anlaşııım & 396 & 71,3 \\
Her İkisiyle de Anlaşamam & 5 &, 9 \\
\hline Toplam & 555 & 100 \\
\hline
\end{tabular}


Tablo 6'da 41 katılımcı $(\% 7,4)$ marka mağazalarından alışveriş yaparken, erkek pazarlama veya satış görevlisi ile daha iyi iletişim kurduklarını (anlaştıklarını/sempati duyduklarını), 113 katılımcı $(\% 20,4)$ ise marka mağazalarından alışveriş yaparken, bayan pazarlama veya satış görevlisi ile daha iyi iletişim kurduklarını (anlaştıklarını/sempati duyduklarını) belirtmişlerdir. 396 katılımcı $(\% 71,3)$ marka mağazalarından alışveriş yaparken, her iki cinsiyette olan pazarlama veya satış görevlisi ile daha iyi iletişim kurduklarını (anlaştıklarını/sempati duyduklarını), 5 katılımcı $(\%, 9)$ ise, marka mağazalarından alışveriş yaparken, her iki cinsiyette olan pazarlama veya satış görevlisi ile iyi iletişim kuramadıklarını (anlaşamadıklarını/sempati duymadıklarını) ifade etmişlerdir.

Tablo 7

Iş̧letmelerin Marka Mağazalarında Pazarlama ve Satış Görevlisi Cinsiyet Tercihlerinin Diğer İşletmelerle Rekabette Önemli Olma Durumlart

\begin{tabular}{lcc}
\hline İşletmelerin Marka Mağazalarında Pazarlama ve Satış Görevlisi Cinsiyet & f & \% \\
Tercihlerinin Diğer İşletmelerle Rekabette Önemli Olma Durumları & 187 & 33,7 \\
\hline Evet & 156 & 28,1 \\
Hayır & 212 & 38,2 \\
\hline Kısmen & 555 & 100 \\
\hline Toplam & & \\
\hline
\end{tabular}

Tablo 7'de, 187 katılımcı (\%33,7), işletmelerin marka mağazalarında çalıştırdıkları pazarlama ve satış görevlisi cinsiyet tercihlerinin diğer işletmelerle yaptıkları rekabette önemli olduğunu, 156 katılımcı $(\% 28,1)$ ise rekabette önemli olmadığını belirtmişlerdir. 212 katılımcı $(\% 38,2)$ ise, işletmelerin marka mağazalarında çalıştırdıkları pazarlama ve satış görevlisi cinsiyet tercihlerinin diğer işletmelerle yaptıkları rekabette kısmen önemli olduğunu ifade etmişlerdir.

Tablo 8

Ölçekte Yer Alan Faktörlerin Katılımcıların Demografik Farklılıkları İle İşletme Pazarlama Satış Görevlisi Cinsiyetin Alışverişe Etkisine İlişkin Tek Yönlü Varyans Analiz Test Sonuçları

\begin{tabular}{|c|c|c|c|c|c|c|c|}
\hline \multicolumn{2}{|c|}{$\begin{array}{l}\text { Katılımcı Özelliklerine Göre } \\
\text { Farklılık }\end{array}$} & \multirow{2}{*}{$\begin{array}{c}\begin{array}{c}\text { Karelerin } \\
\text { Toplamı }\end{array} \\
1.038 \\
\end{array}$} & \multirow{2}{*}{$\frac{\text { sd }}{2}$} & $\begin{array}{c}\text { Karelerin } \\
\text { Ortalaması }\end{array}$ & $\mathbf{F}$ & $\mathbf{P}$ & $\begin{array}{l}\text { Farkın Kaynağı } \\
\text { (Tukey) }\end{array}$ \\
\hline \multirow{3}{*}{$\begin{array}{l}\text { Medeni Duruma } \\
\text { Göre }\end{array}$} & Gruplararası & & &, 519 & \multirow{3}{*}{,918 } & \multirow{3}{*}{, 400 } & \multirow{3}{*}{-} \\
\hline & Grupiçi & 312,385 & 552 &, 566 & & & \\
\hline & Toplam & 313,423 & 554 & & & & \\
\hline \multirow{3}{*}{$\begin{array}{l}\text { Eğitim } \\
\text { Durumuna Göre }\end{array}$} & Gruplararas1 & 1,545 & 4 & ,386 & \multirow{3}{*}{,681 } & \multirow{3}{*}{,605 } & \multirow{3}{*}{ - } \\
\hline & Grupiçi & 311,878 & 550 & 567 & & & \\
\hline & Toplam & 313,423 & 554 & & & & \\
\hline \multirow{3}{*}{ Yaşa Göre } & Gruplararası & 1,691 & 4 &, 423 & \multirow{3}{*}{,746 } & \multirow{3}{*}{, 561} & \multirow{3}{*}{-} \\
\hline & Grupiçi & 311,732 & 550 & 567 & & & \\
\hline & Toplam & 313,423 & 554 & & & & \\
\hline \multirow{3}{*}{ Mesleğe Göre } & Gruplararas1 & ,830 & & ,092 & \multirow{3}{*}{,161 } & \multirow{3}{*}{,997 } & \multirow{3}{*}{-} \\
\hline & Grupiçi & 312,594 & &, 574 & & & \\
\hline & Toplam & 313,423 & & & & & \\
\hline \multirow{3}{*}{ Gelire Göre } & Gruplararası & 1,512 & 3 & ,504 & \multirow{3}{*}{,891 } & & \multirow{3}{*}{ - } \\
\hline & Grupiçi & 311,911 & 551 &, 566 & & ,446 & \\
\hline & Toplam & 313,423 & 554 & & & & \\
\hline \multirow{3}{*}{$\begin{array}{l}\text { Cinsiyete Dikkat } \\
\text { Etmeye Göre }\end{array}$} & Gruplararas1 & 2,022 & 2 & 1,011 & \multirow{3}{*}{\multicolumn{2}{|c|}{ 168, 1,792 }} & \multirow{3}{*}{-} \\
\hline & Grupiçi & 311,401 & 552 &, 564 & & & \\
\hline & Toplam & 313,423 & 554 & & & & \\
\hline Cinsiyetin & Gruplararası &, 069 & 2 & 035 & \multirow{3}{*}{,061 } & & \multirow{3}{*}{-} \\
\hline Alısverişe & Grupiçi & 313,354 & 552 &, 568 & & ,941 & \\
\hline Etkisine Göre & Toplam & 313,423 & 554 & & & & \\
\hline \multicolumn{2}{|c|}{ Cinsiyet İletişimi Gruplararası } & ,859 & 3 & 286 & & & \\
\hline Alışverişe & Grupiçi & 312,564 & 551 &, 567 &, 505 & 679 & \\
\hline Etkisine Göre & Toplam & 313,423 & 554 & & & & \\
\hline İşletme & Gruplararas1 & 6,453 & 2 & 3,226 & & & Pazarlama ve Satıș \\
\hline Pazarlama ve & Grupiçi & 306,971 & 552 &, 556 & & & Görevlisi Cinsiyetinin \\
\hline
\end{tabular}




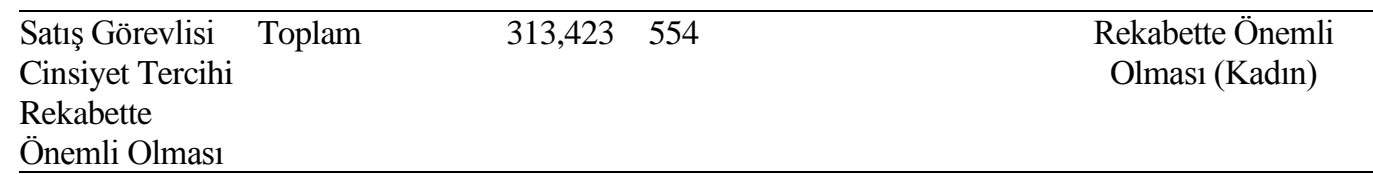

Katılımcıların demografik farklılıkları ile marka mağaza zincirlerindeki pazarlama ve satış görevlisi cinsiyetlerinin alışverişe etkisine ilişkin görüşleriyle, marka mağaza zincirlerindeki pazarlama ve satıș görevlilerinin cinsiyetlerinin müșterilerinin satın alma eğilimine yönelik tutum ölçeğine göre anlamlı bir farkl1lık gösterip göstermediği tek yönlü ANOVA analizi ile test edilmiştir. Katılımcıların özelliklerine göre medeni duruma göre $\left(\mathrm{F}_{(14-291)}=, 918 ; \mathrm{P}>0,05\right)$, eğitim durumuna göre $\left(\mathrm{F}_{(14-291)}=, 681 ; \mathrm{P}>0,05\right)$, yaşa göre $\left(\mathrm{F}_{(14-291)}=, 746 ; \mathrm{P}>0,05\right)$, mesleğe göre $\left(\mathrm{F}_{(14-291)}=, 746 ; \mathrm{P}>0,05\right)$ ve gelire göre $\left(\mathrm{F}_{(14-291)}=, 891 ; \mathrm{P}>0,05\right)$ ölçek alt boyutları arasında anlamlı bir farklılık çıkmamıştır. Yine ANOVA testi sonuçlarına göre, katılımcıların marka mağaza zincirlerindeki pazarlama ve satış görevlisi cinsiyetlerine dikkat etmeye göre medeni duruma göre $\left(\mathrm{F}_{(14-291)}=1,792 ; \mathrm{P}>0,05\right)$, marka mağaza zincirlerindeki pazarlama ve satış görevlisi cinsiyetlerinin katılımcıların alışverişine etkisine göre $\left(\mathrm{F}_{(14-291)}=, 061 ; \mathrm{P}>0,05\right)$ ve tüketici ile pazarlama ve satı̧̧ görevlileri arasındaki cinsiyet iletişimine göre $\left(\mathrm{F}_{(14-291)}=, 505 ; \mathrm{P}>0,05\right)$ ölçek faktörleri arasında anlamlı bir farklılık çıkmamıştır.

Sadece marka mağaza zincirlerindeki pazarlama ve satış görevlisi cinsiyet tercihlerinin rekabette önemli olması $\left(\mathrm{F}_{(14-291)}=5,802 ; \mathrm{P}<0,05\right)$ ile ölçek faktörleri arasında anlamlı bir farklılık çıkmıştır. Farkın kaynağını tespit etmek amacıyla yapılan Tukey testinde; Mersin șehrinde bulunan Forum Mersin Alışveriş Merkezi içerisinde yer alan marka mağazalarından alışveriş yapan tüketicilerin alışveriş yaptıkları mağaza içerisinde, işletmelerin pazarlama ve satış görevlileri tercihlerinde erkek pazarlama ve satış görevlisini tercih etmesi işletmeler arası rekabette önemli algılaması bakımından anlamlı bir farklılık olduğu sonucuna ulaşılmıştır.

\section{Sonuç ve Öneriler}

Marka olabilme sürecinde tüketicilerin satın aldıkları ürünün veya işletmenin topluma veya müşterilerine ne kadar fayda sağladıkları ile ne yaptıklarının yanı sıra, tüketiciler açısından sadece bir ürünün maddi değeri ve kalitesi onu satın almak için yeterli olmamaktadır (Çiftçioğlu ve Gök, 2018, s. 183). Tüketicilerin satın alma davranış kalıplarını belirlemede istek ve ihtiyaçlarının neler olduğunu öğrenerek doğru tespit etmek ve bu doğrultuda belirli pazarlama stratejileri geliştirerek tüketicilerin neyi, nereden, nasıl satın aldığını öğrenmek ve karar alma sürecinde ne gibi faktörlerin etkili veya önemli olduğunu belirlemek işletme satışlarına proaktif katkı sağlamaktadır (Çetin, 2016, s. 23). Bazı toplum ve coğrafi bölgelere göre tüketici tercihlerinde cinsiyet farklılıkları belirgin olarak dikkat çekerken, bazı bölgelerde ve toplumlarda tüketimde cinsiyetler arası farklılıklar görülmemektedir (Çekiç, 2016, s. 90). Pazarlama ve satış açısından cinsiyet faktörünü analiz eden işletmeler, bazı toplum ve coğrafi bölgelere göre satın alma sırasında tüketicilerle pazarlama veya satış görevlisi cinsiyetinin aynı veya farklı olması durumunda cinsiyet anlaşması veya iletişimi belirgin olarak dikkat çekerken, bazı bölgelerde ve toplumlarda satın alma sırasında tüketicilerle pazarlama veya satış görevlisi cinsiyetinin aynı veya farklı olması durumunda cinsiyet anlaşması veya iletişiminde cinsiyetler arası farkl11ıklar görülmemektedir.

Araştırma, 01-31 Ağustos 2020 tarihleri arasında, Mersin şehri forum mersin alışveriş merkezi içerisinde marka mağaza zincir işletmelerinden alışveriş yapan ve yargısal olarak seçilen 555 tüketiciyle yüzyüze yapılan anketlerden elde edilen verilerin analiz edilmesiyle gerçekleştirilmiştir. Katılımcıların önemli bir bölümü \%80'e yakını yılda en az 5 defa marka mağaza zincirlerinden alışveriş yaptıklarını, yarısından fazlası (\%58) marka mağaza zincir işletmelerden alışveriş yaparken pazarlama ve satış görevlilerinin cinsiyetlerine dikkat etmediklerini olduklarını belirtmişlerdir. Yine katılımcıların yarısından fazlası (\%56) marka mağaza zincir işletmelerden alışveriş yaparken, pazarlama ve satış görevlisi cinsiyetinin alışverişlerinde etkili olmadığını ancak marka mağazalardan alışveriş yaparken pazarlama ve satış görevlisi cinsiyetlerinin müşteri iletişiminde etkili (\%51 etkili/kısmen etkili) olduğunu belirtmektedir. Bu durum, marka mağaza pazarlama ve satış görevlisi cinsiyetinin müşterilerinin alışverişlerinde etkili olmadığını ama mağaza pazarlama ve satış görevlisi 
ile müşteri arasındaki cinsiyet iletişiminde/ cinsiyet anlaşmasında önemli olduğunu ortaya koymaktadır. Yine araştırmada ortaya çıkan dikkat çekici diğer bir önemli bulgu, katılımcıların, büyük bir bölümü (\%70) marka mağaza zincir işletmelerden alışveriş yaparken, pazarlama ve satış görevlilerinin her iki cinsiyetle de iyi anlaştıklarını ve işletmelerin pazarlama ve satış görevlisi cinsiyet tercihlerinin diğer işletmelerle yaptıkları rekabette önemli olduğunu belirtmişlerdir. $\mathrm{Bu}$ sonuç, tüketicilerin işletmelerin mağazalarında çalıştırdıkları pazarlama ve satış görevlisi cinsiyet tercihlerinin diğer işletmelerle arasındaki rekabeti etkilediğini ve pazarlama ve satış görevlisi cinsiyet tercihinin rekabette önemli olduğunu ortaya koymaktadır. Ayrıca, Mersin şehri Forum Mersin Alışveriş Merkezi içerisinde yer alan marka işletme mağazalarından alışveriş yapan tüketicilerin alışveriş yaptıkları mağaza içerisinde, işletmelerin pazarlama ve satış görevlileri tercihlerinde erkek pazarlama ve satış görevlisini tercih etmesinin işletmeler arası rekabette önemli algılaması bakımından anlamlı bir farklılık olduğu sonucuna ulaşılmıştır.

Bu kapsamda araştırmada elde edilen bulgulara göre ifade edilen $\mathrm{H} 10$ hipotezi haricindeki tüm hipotezler reddedilmiştir. Buna ilişkin olarak marka mağazalarından alışveriş yapan müşteriler işletme tarafından pazarlama ve satış görevlisi cinsiyet tercihinin alışverişlerini etkilemediği ancak işletmeler arası rekabette işletme tarafından pazarlama ve satış görevlisi cinsiyet tercihinin alışverişini etkilediği sonuçlarına ulaşı1mıştır.

Çalışma, 01-31 Ağustos 2020 tarihleri ile Mersin şehri Forum Mersin alışveriş merkezi içerisindeki marka mağaza zincir işletmelerden alışveriş yapan 555 tüketici ile sınırlandırılmıştır.

Gelecekte yapılacak çalışmalarda ise, "Ürün özelliği ve sektör yapısına göre marka mağaza zincirlerindeki pazarlama ve satı̧̧ görevli cinsiyetlerinin etkisi ve önemi", "Coğrafi bölge ve toplum yapısına göre marka mağaza zincirlerindeki pazarlama ve satış görevli cinsiyetlerinin etkisi ve önemi”, "marka mağaza zincirlerindeki pazarlama ve satış görevli cinsiyet tercihlerinin markaya etkisi" gibi konular, teorik ve uygulamalı olarak incelenebilir. Ayrıca, marka mağaza zincirlerindeki pazarlama ve satış görevli cinsiyetleri konusu tüketiciler tarafından farklı değerlendirilebilmesi sebebiyle bölgesel, ulusal ve uluslararası düzeyde karşılaştırmalı araştırmalar yapılabilir.

Araştırmanın literatüre ve idari çıkarımlara en büyük katkısı, pazarlama ve satış çıktıları açısından, pazarlama ve satış görevlileri ile müşteriler arasındaki cinsiyet temelli benzerlik ve/veya farklılıklara ilişkin cinsiyet anlaşma veya iletişimi (empati, sempati ve antipati oluşumunda) ile ilgili bilgilerin yeni ve farklı bir yaklaşımla zenginleştirilmesidir. Yine araştırma bulgularının kamuoyunun bilgi ihtiyacını gidermeye katkı sağlamasının yanı sıra, başta pazarlama ve satış yöneticileri ile marka mağaza işletmelerine ve kamuoyuna, pazarlama veya satış görevlisi ile müşteri arasında cinsiyet anlaşması veya iletişiminde etkin olarak kullanılabileceği düşünülmektedir.

\section{Yazarların Katkı Oranı}

Çalışma tek yazarlı olduğu için yazarın katkı oranı \%100'dür.

\section{Çıkar Çatışması}

Çıkar çatışması teşkil edebilecek bir durum yoktur.

\section{Kaynaklar}

Acar, S. (2012). Kurumsal markaların tüketicilerin satın alma davranışı üzerine etkisi ve uygulama. Yüksek Lisans Tezi. İstanbul Ticaret Üniversitesi, Sosyal Bilimler Enstitüsü, İstanbul.

Akdoğan, Ş. ve Karaarslan, M. H. (2010). Mağaza içerisinde tüketicinin kararını yönlendiren kişilerin etkisinin senaryo yöntemi ile ölçülmesi. Tüketici ve Tüketim Araştırmaları Dergisi, 2(2), 29-48. 
Arnold, K. A., and Bianchi, C. (2001). Relationship marketing, gender, and culture: Implications for consumer behavior. ACR North American Advances.

Arnould, E., J., Price, L. and Zinkhan, G. M. (2002). Consumers. McGraw-Hill/Irwin: NewYork, USA.

Avery, J. (2012). Defending the markers of masculinity: consumer resistance to brand gender-bending. International Journal of Research in Marketing, 29(4), 322-336.

Bakshi, S. (2012). Impact of gender on consumer purchase behaviour. Journal of Research in Commerce and Management, 1(9), 1-8.

Bal, M. (2012). Çalışan personelin kurumsal imaj oluşumuna etkisi. Kahramanmaraş Sütçü İmam Üniversitesi İktisadi ve İdari Bilimler Fakültesi Dergisi, 2(1), 219-241.

Barletta, M. (2003). Marketing to women: How to understand, reach, and increase your share of the world's largest market segment. Chicago: Dearborn Trade Publishing.

Başfırıncı, Ç., Ergül, B. ve Özgüden, B. (2018). İzleyici gözünden toplumsal cinsiyete meydan okuyan reklamlar. International Journal of Economic \& Administrative Studies, (20), 199-216.

Chang, C. T. and Tung, M. H. (2016). Intergenerational appeal in advertising: impacts of brandgender extension and brand history. International Journal of Advertising, 35(2), 345-361.

Cleveland, M., Babin, B., Laroche, M., Ward, P. and Bergeron, J. (2003). Information search patterns for gift purchases: A cross-national examination of gender differences. Journal of Consumer Behavior: An International Research Review, 3(1), 20-47.

Çabuk, S. ve Araç, S. K. (2013). Psikografik bir pazar bölümlendirme değişkeni olarak cinsiyet kimliği: Tüketim araştırmalarında cinsiyet kimliği kavramının incelenmesi. Çukurova Üniversitesi Sosyal Bilimler Enstitüsü Dergisi, 22(2), 27-40.

Çekiç, S. (2016). Davranışsal iktisat bağlamında cinsiyet farkının tüketici tercihlerine etkisi: Bartın örneği. Yüksek Lisans Tezi. Bartın Üniversitesi, Sosyal Bilimler Enstitüsü, Bartın.

Çetin, K. (2016). Kadın tüketicilerin giysi satın alma davranışları ve marka bağımlılığı. Ahi Evran Üniversitesi Sosyal Bilimler Enstitüsü Dergisi, 2(2), 22-40.

Çiftçioğlu, B. A. ve Gök, B. (2018). Kurumsal sosyal sorumluluğun kurumsal itibara etkisi ve bir uygulama. Ahi Evran Üniversitesi Sosyal Bilimler Enstitüsü Dergisi, 4(2), 183-196.

Dökmen, Z., Y. (2015). Toplumsal cinsiyet: Sosyal psikolojik açıklamalar. İstanbul: Remzi Kitapevi.

Efe, Ü. (2017). Marka genişlemesi stratejisi ve Türkiye'deki bazı ünlü markaların marka genişlemesi deneyimleri. Journal of International Social Research, 10(48), 606-613.

Fischer, E. and Arnold, S., C. (1990). More than a labor of love: Gender role and christmas gift shopping. Journal of Consumer Research, 17, 333-345.

Grohmann, B. (2009), Gender dimensions of brand personality. Journal of Marketing Research, (45), 105-119.

İri, R. (2020). The scale for the attitudes of customers towards purchasing tendency within the context of business, marketing and sales officers' genders: A validity and reliability study. Business \& Management Studies: An International Journal (BMIJ), 8(3), 2776-2792. 
Karahan, F. D. (2018). Tüketim toplumunda alışverişin cinsiyeti. Bildiriler Kitabı-IV, 169, 187-197.

Karahan, F. D. ve Adak, N. (2019). Tüketimin cinsiyeti: Tüketim toplumunda gençlerin tüketim eğilimleri. Akdeniz Kadın Çalışmaları ve Toplumsal Cinsiyet Dergisi, 2(1), 118-148.

Kılıçer, T., Boyraz, E. ve Tüzemen, A. (2016). Kadın, erkek, ya da? Hediye satın alma davranışında cinsiyet kimliği rolünün etkisi. Ege Academic Review, 16(1), 121-133.

Lieven, T. (2016). Customers choice of a salesperson during the initial sales encounter. Journal of Retailing and Consumer Services, 32, 109-116.

Odabaşı, Y. ve Barış, G. (2007). Tüketici davranışı. İstanbul: MediaCat Kitapları.

Peker, A., Özkan, E. ve Okumuş, A. (2017). Marka genişlemesine yönelik tüketici tutumlarına etki eden faktörlerin yerli ve yabancı markalı ürünler açısından karşılaştıılması. Kırklareli Üniversitesi İBF Dergisi, 6(3), 19-37.

Peterson, R., A. (2005). Response construction in consumer behavior research. Journal of Business Research, 58, 348-353.

Strouse, A., W. (2019). Gender Trouble Couplets, Volume 1.

Tanrıkulu, C. (2017). Sex and gender identity differences in psychological job outcomes among salespeople. Revista Brasileira de Gestão de Negócios, 19(66), 499-519.

Tayfun, N. Ö. (2015). Market alışverişlerinde plansız satın alma davranışında demografik farklılığı belirlemeye yönelik bir araştırma. Selçuk Üniversitesi Sosyal Bilimler Enstitüsü Dergisi, (34), 87-94.

Yağc1, M. İ. ve İlarslan, N. (2010). The effect of advertisements and gender identity role on consumer buying behavior. Doğuş University Journal, 11(1), 138-155.

Yıldırım, Y. ve Büyükateş, S. (2020). Yazı tipi, yazı karakteri ve yazı renginin marka cinsiyet algılamasına etkisi. Business \& Management Studies: An International Journal, 8(2), 2215-2244.

Yıldırım, Y. ve Kömürcü, A. H. (2019). Marka cinsiyetinin çeşitli markalar açısından değerlendirilmesi ve pazarlama stratejilerine yönelik öneriler. Yönetim ve Ekonomi Araştırmaları Dergisi, 17(2), 150-174. 


\section{Extended Abstract}

\section{Introduction}

Institutionalized or branded businesses do not give up retailing activities in their show rooms or stores. According to the ability to ask questions and answer questions they carry out in brand stores, marketing and sales representatives may have a purchase decision as a question and answer. Businesses analyzing marketing and sales differentiation draw attention to purchasing purchasing agreements or communication with consumers when the gender of the marketing or sales task is the same or different, according to some societies and regions, while the marketing or officer gender that occurs during the purchase in some ranks and societies is the same. or differences between gender differences in gender agreement or communication. At the same time, the marketing gender, the same or different gender of marketing or sales duty with the consumers during the purchase, can be important in the realization of the agreement or communication (in the formation of empathy, sympathy and antipathy) between the customer and the marketer.

To provide marketing and sales services to customers and counterparties in many companies, especially in the service sector. The fact that the marketing or salesperson who can make or direct the decisions of the consumers whose purpose is to shop is important, reveals the need to do it in this business. Gender agreement / compliance or disagreement of gender of marketing and salespeople continues in the context of business and marketing in their attitudes towards the purchasing tendency of consumers. In the literature, a lot of study on user purchasing of the genders of business marketing and salespeople has made it remarkable to investigate the buying tendency of the genders of business marketing and salespeople to take over.

This issue was chosen as a research problem due to the increase in complaints with marketing and sales representatives of customers who shop from brand chain stores in shopping centers. Although there are many studies in the literature on the concepts related to the relationship between brand store chains and the purchasing tendencies of consumers, no academic research has been conducted on the purchasing perceptions of the marketing and salesperson genders in the brand store chains.

\section{Method}

The research was conducted between 01-31 August 2020 and covers consumers who shop from brand business stores in Forum Mersin (AVM) Shopping Center. In the judicial selection of the consumers in the shopping mall, it was aimed to obtain more accurate information within the scope of the research, as well as to be more knowledgeable about the general brand business stores. Within the scope of the research, a survey was conducted with consumers who shop from brand chain stores located in Forum Mersin Shopping Center in Mersin city.

The descriptive statistics and one-way ANOVA analyzes conducted in the study were examined, and in line with the information obtained, it was prepared by using the "Attitude Scale towards the Purchase Tendency of the Customers of the Marketing and Salesperson Gender in Business Stores" developed by İri (2020). A questionnaire has been prepared. The questionnaire forms were conducted with the data obtained from face-to-face surveys with 555 judicially selected consumers who shop from a total of 206 national and international corporate (brand) business stores located in Forum Mersin Shopping Mall in the city center of Mersin. The data obtained from the surveys were evaluated in the SPSS 22.0 package program, and a total of 555 consumer samples selected judicially among the consumers who shop from brand store chain businesses in Mersin and its region, which constitute the main mass of the study, were taken. It is assumed that a sample of this size will adequately represent the available population at a confidence interval of $-95 \%$.

Necessary permission was granted for the study by the Ethics Committee of Niğde Ömer Halisdemir University dated 28.07.2020 and numbered 86837521-050,99-E, 32490 Ethics Committee. 
According to the analysis, the approach towards the attitude of corporate business (brand) business marketing and salespeople towards the gender buying tendency has become meaningful only among the scales of the business being important in the competition between marketing and salespeople's gender preferences. To determine the source of the difference In Tukey test; It has been concluded that among the meaningful list of the gender preferences of marketing and salespeople of businesses in competition among companies, it is in favor of female marketing and salespeople.

\section{Findings}

One-way ANOVA analysis was used to test whether participants 'demographic differences and their views on the effect of marketing and salesperson gender in brand store chains on shopping, and whether the gender of marketing and salespeople in brand chain stores differ significantly according to the attitude scale of their customers' buying tendency. According to the characteristics of the participants, according to marital status $\left(\mathrm{F}_{(14-291)}=, 918 ; \mathrm{P}>0.05\right)$, by education level $\left(\mathrm{F}_{(14-291)}=, 681\right.$; $\mathrm{P}>0.05)$, by age $\left(\mathrm{F}_{(14-291)}=, 746 ; \mathrm{P}>0.05\right)$, by occupation $\left(\mathrm{F}_{(14-291)}=, 746 ; \mathrm{P}>0.05\right)$ and by income $(\mathrm{F}$ $(14-291)=, 891 ; \mathrm{P}>0.05)$, there was no significant difference between scale sub-dimensions. Again, according to the results of ANOVA test, according to the marital status $\left(\mathrm{F}_{(14-291)}=1.792 ; \mathrm{P}>0.05\right)$, according to the effect of the gender of marketing and salespeople in brand store chains on the shopping of the participants, $\left(\mathrm{F}_{(14-291)}=.061 ; \mathrm{P}>0.05\right)$ and according to gender communication between consumer and marketing and salespeople $\left(\mathrm{F}_{(14-291)}=, 505 ; \mathrm{P}>0.05\right)$ there was no difference. A significant difference was found between the scale factors, with only the marketing and salesperson gender preferences in the brand chain stores being important in competition $\left(\mathrm{F}_{(14-291)}=5.802 ; \mathrm{P}\right.$ $<0.05)$. In the Tukey test conducted to determine the source of the difference; It has been concluded that there is a significant difference in terms of the perception that the consumers who shop from brand stores in the Forum Mersin Shopping Center in Mersin city prefer male marketing and salespeople in their marketing and salesperson preferences.

\section{Conclusion, Discussion and Recommendations}

A significant portion of the participants stated that nearly $80 \%$ of them shop at least 5 times a year from brand store chains, and more than half (58\%) of them do not pay attention to the gender of the marketing and sales personnel while shopping from brand store chain businesses. Again, more than half of the participants (56\%) stated that while shopping from brand store chain businesses, marketing and salesperson gender is not effective in their shopping, but marketing and salesperson gender are effective (51\% effective / partially effective) in customer communication when shopping from brand stores. This situation reveals that the brand store marketing and salesperson gender is not effective in the purchases of their customers, but is important in the gender communication / gender agreement between the store marketing and sales staff and the customer.

Another remarkable finding that emerged in the study is that while most of the participants (70\%) shop from brand store chain businesses, marketing and salespeople get along well with both genders, and the marketing and salesperson gender preferences of the businesses are important in their competition with other businesses. They stated that. This result reveals that the marketing and salesperson gender preferences that consumers employ in the stores of the businesses affect the competition with other businesses and the marketing and salesperson gender preference is important in competition. In addition, it has been concluded that consumers who shop from brand business stores located in Forum Mersin Shopping Mall in Mersin city prefer male marketing and salespeople in their marketing and salesperson preferences, which is a significant difference in terms of perception of competition between businesses. 